\title{
ЕФЕКТИВНІСТЬ ВИКОНАННЯ КОМП'ЮТЕРНО-ГЕНЕРОВАНИХ ВПРАВ 13 ПРЕДМЕТА «ІНФОРМАЦІЙНІ ТЕХНОЛОГІЇ В ФАРМАЦІЇ» НА ОСНОВІ КОГНІТИВНИХ ПРОТОТИПІВ
}

\begin{abstract}
А. М. Попов
Запорізький державний медичний університет

У статті представлено розроблену технологію навчання. Показано ефективність представлення навчальних декларативних знань на основі прототипів когнітивних структур людини для підвищення якості трансферу знань у системі студент-комп'ютер. Результати підтвердили гіпотезу про якісніше та швидкіше засвоєння навчальних декларативних знань із предмета, представлених у вигляді прототипів когнітивних структур людини. Побудована лінія тренду на діаграмі успішності студентів контрольної та експериментальної груп протягом десяти занять засвідчила стабільне прискорення нарощування рівня засвоєння знань студентами експериментальної групи відносно контрольної, а також поліпшення загального рівня академічної успішності.
\end{abstract}

Ключові слова: когнітивний прототип, дистанційне навчання, інтелектуальна навчальна система, ефективність навчання, інформаційні технології у фармації.

\section{ЭФФЕКТИВНОСТЬ ВЫПОЛНЕНИЯ КОМПЬЮТЕРНО-ГЕНЕРИРУЕМЫХ УПРАЖНЕНИЙ ПО ПРЕДМЕТУ «ИНФОРМАЦИОННЫЕ ТЕХНОЛОГИИ В ФАРМАЦИИ» НА ОСНОВЕ КОГНИТИВНЫХ ПРОТОТИПОВ}

А. Н. Попов

\author{
Запорожский государственный медицинский университет
}

\begin{abstract}
В статье представлена эффективность трансфера знаний в системе студент-компьютер при помощи технологии обучения на основе прототипов когнитивных структур личности. Проведен анализ академической успеваемости студентов, выполнявших самостоятельную работу по курсу "Информационные технологии в фармации" на основе когнитивных прототипов. Результаты исследования подтвердили гипотезу о более качественном и быстром усвоении учебных декларативных знаний, представленных в виде прототипов когнитивных структур человека. Результаты входных тестирований в течение учебного времени подтвердили лучшую в среднем на $10 \%(p<0,05)$ теоретическую подготовку студентов экспериментальной группы, которые в процессе подготовки ко входному тестированию работали над упражнениями в формате когнитивных структур. Построение линии тренда на диаграмме успеваемости студентов контрольной и экспериментальной групп в течение десяти занятий позволило увидеть существенную разницу между углами наклона этой линии в контрольной и экспериментальной группах соответственно, что может свидетельствовать о стабильном ускорении наращивания уровня усвоения знаний студентами экспериментальной группы относительно контрольной, а также об улучшении уровня академической успеваемости.
\end{abstract}

Ключевые слова: когнитивный прототип, дистанционное обучение, интеллектуальная обучающая система, эффективность обучения, информационные технологии в фармации.

\section{EFFICIENCY OF COMPUTER-GENERATED TRAINING EXERCISES OF THE SUBJECT «INFORMATION TECHNOLOGIES IN PHARMACY» BASED ON COGNITIVE PROTOTYPES}

\section{Zaporizhzhya State Medical University}

A. M. Popov

The paper describes a research to corroborate a hypothesis that working on training exercises based on prototypes of human cognitive structures helps enhance student's knowledge digestion and engagement in learning process, gain a higher level of their progress in studies and achieve a better academic performance. The results of the research confirmed the hypothesis of better and more rapid digestion of declarative knowledge on the subject of "Information Technologies in

(C) А. М. Попов 


\section{МЕДИЧНА ІНФОРМАТИКА TA ІНЖЕНЕРІЯ}

Pharmacy", represented in the form of prototypes of human cognitive structures. The results of the entrance test controls showed better on average by $10 \%(p<0.05)$ theoretical achievements of students in the experimental group who worked on training exercises in the format of cognitive structures. Drowning a chart of students' performance in control and experimental groups for ten lessons and a trend line (linear regression) on it allowed us to highlight the significant difference in the inclinations of the lines with indices of 0.067 and 0.111 in the control and experimental group, respectively. This indicated a stable acceleration of knowledge by students in the experimental group in comparison with the control group and proved an enhanced academic performance among the groups of students.

Key words: cognitive prototype, distance learning, intelligent educational system, efficiency of instruction, information technologies in pharmacy.

Вступ. Розробка та впровадження ефективних інтелектуальних систем дистанційного навчання сьогодні є актуальним завданням, що обумовлено зростаючими потребами суспільства в якісній освіті, вдосконаленням теоретичної та технічної баз для розроблення таких систем, а такожу зв'язку з потенційною можливістю економії коштів на освіту в період фінансової кризи та військового конфлікту. Активізація самостійної роботи студента, що є необхідним елементом сучасного кредитно-модульного навчання, може бути здійснена на основі когнітивних структур особистості, відкритих фахівцями в галузі когнітивної психології особистості та когнітивної лінгвістики, які являють собою ментальні утворення або інформаційні патерни, на основі яких відбувається сприйняття, структуризація інформації та процес міркування і логічного виводу у свідомості студента [2, 3, 4, $10,11]$. У попередній роботі [6] нами було виявлено когнітивний прототип (КП) як, з одного боку, шаблон для формалізації і структуризації навчальних декларативних знань, і з іншого як патерн репрезентації знань, а також методика побудови еталонної моделі навчального курсу на його основі. У даній роботі формальна структура КП узята за основу для комп'ютерної генерації навчальних завдань $з$ дисципліни "Інформаційні технології у фармації" для активації розумової діяльності студента на етапі самостійної роботи з навчальним матеріалом у вигляді конспекту лекцій, підручників, презентацій та ін. Для активізації та інтелектуалізації самостійної роботи студентів (СРС) нами запропонований підхід, заснований на навчальних вправах особливого типу на основі формальної структури когнітивного прототипу, який дозволяє описувати навчальні поняття відповідно до психологічних особливостей засвоєння знань людиною. Для перевірки якості та темпу засвоєння навчальних декларативних знань, представлених у форматі когнітивних прототипів, була розроблена комп' ютерна інструментальна система «Інтелектуальна система дистанційного навчання на основі КП» (ІСДНКП) [5, 7, 8, 13], що дозволяє створювати еталонну модель навчальних декларативних знань та зберігати іiі у базу даних (БД), а також набір модулів для генерації та організації самостійної роботи студента в розподіленому інформаційному середовищі BH3.

Мета дослідження: експериментальна перевірка ефективності представлення навчальних декларативних знань у форматі когнітивних прототипів для підвищення рівня засвоєння знань студента та загального рівня академічної успішності 3 предмета «Інформаційні технології у фармації».

Теоретичні передумови. Дослідження в галузі когнітивної психології особистості (Дж. Келлі, У. Скотт, О. Харві, Д. Хант, Х. Шродер) та когнітивної експериментальної психології (Ф. Бартлетт, С. Палмер, У. Найссер, Е. Рош, М. Мінський) [12] дозволили виділити в якості предмета досліджень когнітивні структури особистості, на основі яких відбувається сприйняття, засвоєння і збереження інформації у свідомості людини. У змістовному плані когнітивні структури особистості являють собою узагальнено-типізовані системи організації знань, що є одночасно механізмами вилучення, використання і зберігання інформації (Петренко В. Ф.). На сьогоднішній день існує декілька напрямів аналізу когнітивних структур: в рамках загальнопсихологічних знань вони набули статусу універсального суб страту розумового розвитку (Чуприкова Н. I., Ратанова Т. А.), когнітивна лінгвістика орієнтується на поняття речових репрезентативних когнітивних структур як основу мовного розвитку (Панчук С. Ю.), педагогічний аспект вивчення когнітивних структур особистості включає питання їх генезу та проявів (Гальперін П. Я.). У роботі постає завдання використання прототипів когнітивних структур особистості для представлення предметно-орієнтованих знань, і використання цих прототипів у складі інтелектуальної автоматизованої навчальної системи для навчання. В якості прототипів розглядаються поняття, концепти, фрейми, об'єкти, гештальт, схема. Доцільність дослідження можливостей застосування когнітивних прототипів для структурування навчального матеріалу аргументується тим 
що, для підвищення якості навчання необхідний аналіз механізмів засвоєння інформації.

Матеріали та методи дослідження. В дослідженні взяли участь дві групи студентів: експериментальна (30 чоловік) та контрольна (73 чоловіки), які було обрано випадковим методом Монте-Карло. Для аналізу результатів дослідження застосовано методи статистичного аналізу даних (1-тест для незалежних вибірок), трендовий аналіз для оцінювання якості та швидкості нарощування знань, а також методи узагальнення та систематизації досвіду організації самостійної роботи студента в розподіленому інформаційному середовищі медичного ВНЗ.

Дизайн експерименту. Експериментальне дослідження проводилося впродовж другого семестру 10/11 навчального року на кафедрі "Медичної та фармацевтичної інформатики та НТ" Запорізького державного медичного університету. У дослідженні брали участь студенти II-го курсу фармацевтичного факультету. Предметною галуззю виступав обов'язковий для вивчення предмет "Інформаційні технології у фармації". Методом Монте-Карло було обрано експериментальну групу у кількості 30 студентів. До складу контрольної групи увійшли інші студенти потоку у кількості 73 чоловік, які навчалися за традиційною технологією. Впродовж семестру викладачами кафедри "Медичної та фармацевтичної інформатики та НТ" в співпраці з розробниками системи була побудована еталонна модель знань з курсу "Інформаційні технології у фармації", яка включала 10 тем та близько 650 понять й лексем, згрупованих у близько 95 КП, які описували структуру апаратних та програмних засобів, їх особливості та функціональні можливості. Викладачі кафедри створювали контент курсу на основі КП за тією темою, за якою вони були закріплені. По кожній темі студентові пропонувалося від 15 до 30 частково заповнених шаблонів когнітивних прототипів для самостійної роботи у контексті підготовки до складання вхідного тестового контролю у системі ЯЛТ08 [1] перед початком кожного практичного заняття у комп'ютерному класі, починаючи з другого. Тестові завдання у системі ИЛТ08 не були спеціально адаптовані у відповідності до завдань у форматі когнітивних прототипів, використовувались традиційні тести з тестової бази даних. Для організації дослідження нами була розроблена технологія структуризації та репрезентації навчальних понять, розроблена ИМЬ-модель та виконано програмування системи. До завдання розробленого нами модуля студента входило надання студентові інтуїтивно зрозумілого інтерфейсу для управління своїм навчальним планом та роботи над комп'ютерно генерованими вправами самостійної роботи. Для оцінки теоретичної підготовки студента до практичного заняття використовувалась традиційна чотирибальна шкала. Вхідний тестовий контроль містив по кожній темі 15-20 тестових завдань й оцінювався згідно з нижченаведеною схемою: 60-69 \% вірних відповідей - 3 («задовільно»), 70-84 \% - 4 («добре») та 85-100 \% - 5 («відмінно»). Студенти експериментальної групи, які не виконали вчасно самостійну роботу на основі когнітивних прототипів з поточної теми, не включалися до розрахунків. Завдання самостійної роботи пропонувалися студентові у табличному вигляді, як показано на рисунку 1а. Приклади завдань наведено на рисунках 1б-1г. У слоти КП позначені $<$ ?> студент повинен був вписувати відповіді. У ході дослідження були використані такі типи семантичних зв'язків у складі КП-в як «частина-ціле», «рідвид», «об'єкт-функція» тощо. Робота студента була організована таким чином, що студент мав можливість виконувати завдання самостійної роботи протягом певного часу (2-3 доби), відведеного на підготовку до практичного заняття у декілька заходів. Тобто, студент мав можливість виконати частину вправ в один день та решту в інший день, але обов'язково перед практичним заняттям.

Результати та їх обговорення. Результати комп'ютерного вхідного тестування засвідчили, що студенти експериментальної групи, які під час підготовки до вхідних тестів виконували завдання у форматі когнітивних прототипів, отримували більш високі оцінки - середні оцінки (M) студентів експериментальної групи наведені на рисунку 2a. Відносно невисока середня результативність студентів як контрольної, так і експериментальної груп $(3,5-4,5)$ обумовлена технічною спрямованістю курсу, який не є профілюючим для студентів медичного ВНЗ. Проте, студенти експериментальної групи не отримали жодної незадовільної оцінки з жодного з вхідних тестувань, тоді як серед студентів контрольної групи були такі, які набирали менше ніж 60 \% вірних відповідей, тобто отримали незадовільну оцінку. По кожному 310 занять проведено порівняння середніх за допомогою 1-тесту для незалежних вибірок (дані розподілені за нормальним законом), який засвідчив статистично суттєву різницю (з рівнем значущості $\mathrm{p}<0,05$, окрім заняття $4, p=0,14$ ) у середніх значеннях оцінок за вхідний контроль серед студентів експериментальної та контрольної груп (табл. 1). Відхилення від статистично достовірних результатів по четвертому заняттю може бути обумовлене періодом атестації 3 


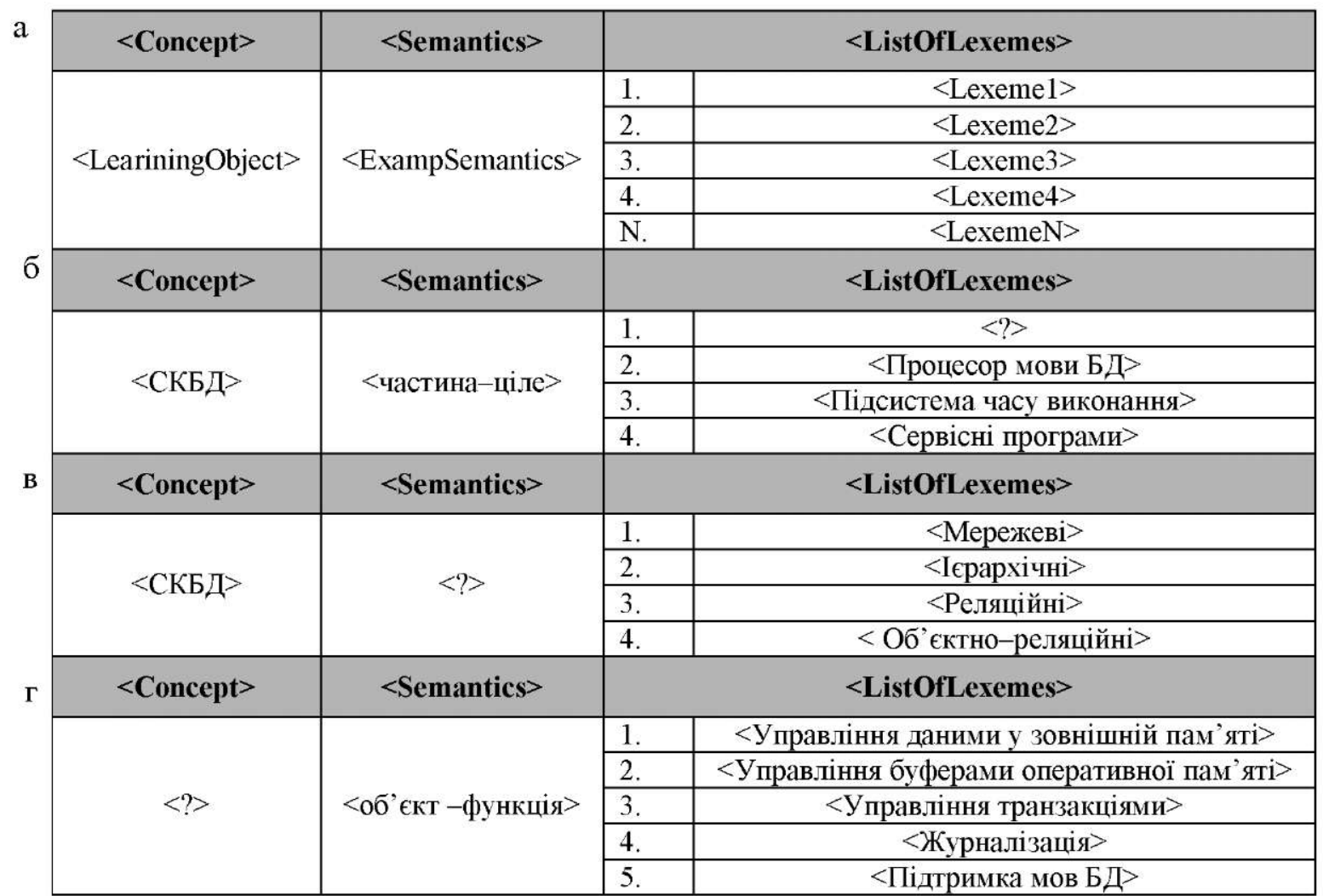

Puc. 1. Структура завдань у вигляді КП а) та приклади завдань по темі № 9 «Системи керування базами даних у фармації» б) (<Ядро>), в) (<рід-вид>), г) (<СКБД>).

інших предметів, яка проходила водночас з четвертим заняттям, що спричинило розсіювання уваги студентів та їх перенавантаженням у цей період. Розраховано середньоквадратичні відхилення від середніх значень (8) для контрольної та експериментальної груп по кожному з 10 занять, дані наведені у таблиці 1. свідчать про більший розкид середніх значень серед студентів контрольної групи окрім заняття 4 та 6. На рисунках 2а та 26 подано графіки з відображенням середньої оцінки за вхідний контроль. Графіки дозволяють побачити стабільну позитивну динаміку середніх оцінок студентів експериментальної групи від першого до останнього заняття. Побудовані лінії тренду на кожному з графіків дозволяють визначити розкид точок а також побачити дані, завдяки яким ми можемо зробити висновок щодо різниці успішності засвоєння знань у групах. Константа рівняння регресії дозволяє побачити, що на початку експерименту рівень знань у групах був приблизно однаковий (середній бал за перший вхідний тестовий контроль був для експериментальної групи - 3,1 , для контрольної 2,9). При цьому, коефіцієнт рівняння рег ресії, побудованих для контрольної та експеримен- тальної груп, дозволяє побачити істотну різницю між рівнем знань у групах на стадії завершення навчання. В експериментальній групі спостерігається значно більший кут нахилу лінії тренду з коефіцієнтом 0,111 , а в контрольній 0,067 , що може свідчити про стабільну динаміку прискорення нарощування рівня засвоєння знань студентами експериментальної групи відносно контрольної. Коефіцієнт детермінації Я $^{2}$ на графіку результатів тестування експериментальної групи $(0,94)$ ближчий до одиниці ніж для контрольної $(0,7)$ групи засвідчив більш явну лінійну залежність між номером заняття та середньою оцінкою за вхідний тестовий контроль, що також можна інтерпретувати як більш послідовне, більш передбачуване (лінійна залежність) та стабільне нарощування знань студентів експериментальної групи від першого до останнього заняття.

На етапі самостійної роботи було виявлено, що найскладнішим типом вправ для студентів виявилися завдання другого типу, аналогічно $з$ дослідженням, який було проведено раніше на базі дисципліни «Паразитологія» [9], в яких від студента вимагалося визначити тип семантичного відношення між поняттями. 
a

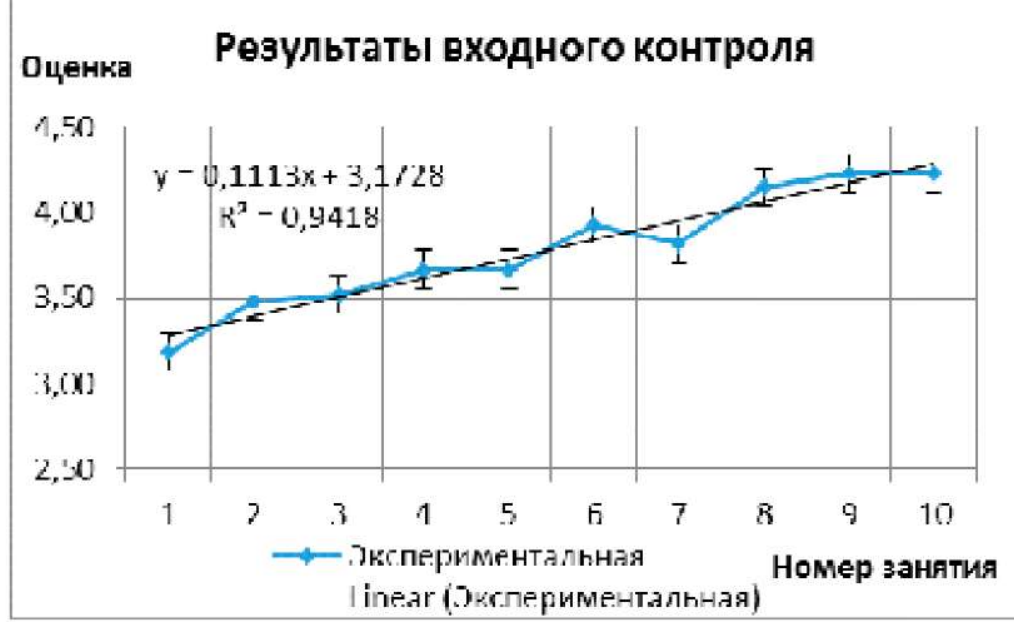

б

Оценка Результаты входного контроля

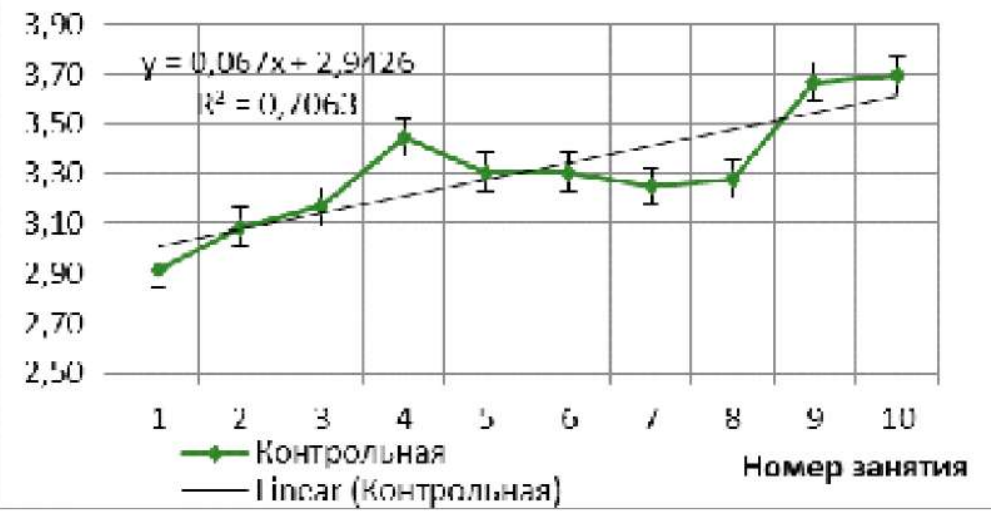

B

Лінійна апраксимація темпу засвоення знань

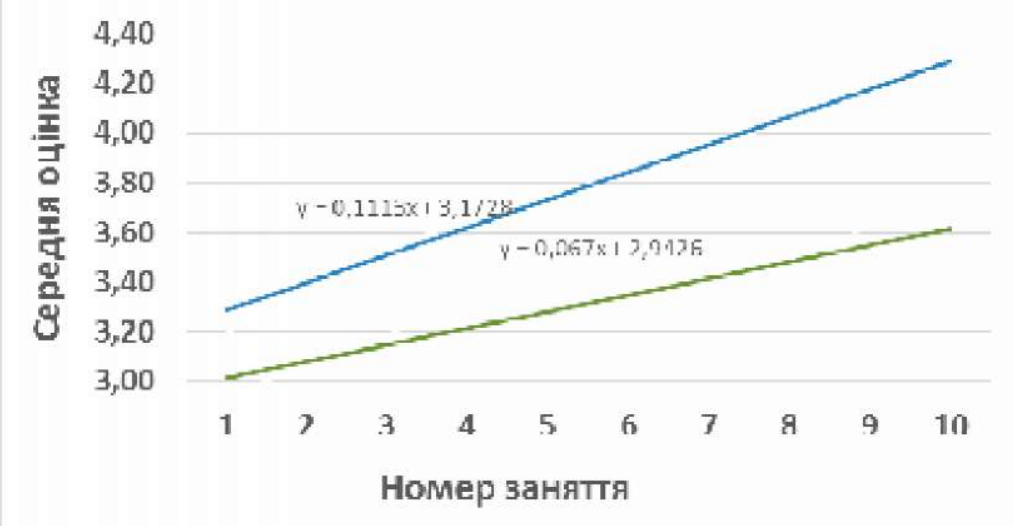

Puc. 2. Динаміка результатів вхідного тестування експериментальної (а) та контрольної (б) груп протягом десяти занять.

Для підвищення результативності студентів по завданнях другого типу рекомендується ретельніше роз'яснювати сенс кожного типу семантичних відношень на етапі первинного інструктажу по роботі з системою та особливості структуризації вузлів КП. 
Таблиця 1. Середня оцінка з вхідного контролю у формі традиційного тестування по кожному з десяти занять та результати 1-тесту для незалежних вибірок

\begin{tabular}{|c|c|c|c|c|c|c|}
\hline № заняття & $\mathrm{M}_{\text {Експеримент }} / \mathrm{n}=30$ & $\mathrm{M}_{\text {Контроль }} / \mathrm{n}=73$ & $\mathrm{~S}_{\mathrm{K}}$ & $\mathrm{s}_{\mathrm{E}}$ & $\mathrm{p}$ & Стат. достовірність \\
\hline 1 & 3,19 & 2,92 & 0,48 & 0,28 & 0,0074 & Так \\
\hline 2 & 3,48 & 3,08 & 0,58 & 0,55 & 0,0075 & Так \\
\hline 3 & 3,52 & 3,17 & 0,70 & 0,44 & 0,018 & Так \\
\hline 4 & 3,67 & 3,44 & 0,55 & 0,61 & 0,14 & Ні \\
\hline 5 & 3,67 & 3,31 & 0,67 & 0,46 & 0,015 & Так \\
\hline 6 & 3,93 & 3,31 & 0,72 & 0,76 & 0,0043 & Так \\
\hline 7 & 3,81 & 3,25 & 0,73 & 0,64 & 0,002 & Так \\
\hline 8 & 4,15 & 3,28 & 0,81 & 0,61 & $9,75 \mathrm{E}-06$ & Так \\
\hline 9 & 4,22 & 3,67 & 0,80 & 0,47 & 0,001 & Так \\
\hline 10 & 4,22 & 3,69 & 0,75 & 0,52 & 0,0017 & \multicolumn{2}{c|}{} \\
\hline
\end{tabular}

Отже, використання когнітивних патернів на етапі самостійної роботи, зокрема студентів які навчаються дистанційно, дозволяє уніфікувати процес самопідготовки при вивченні предмету «Інформаційні технології у фармації», дає можливість використовувати фрагменти вже вивчених онтологій у взаємопов'язаних предметних областях і формалізувати завдання для використання їх в інтелектуальних навчальних системах дистанційної освіти. При цьому репрезентація матеріалу у формі прототипів когнітивних структур відповідає психологічним особливостям засвоєння, зберігання і використання інформації людиною, що підвищує показники успішності студентів при навчанні з використанням вищезазначених навчальних матеріалів на етапі самостійної роботи.

Висновки. Результати дослідження підтвердили ефективність технології навчання на основі когнітивних прототипів, а також гіпотезу про якісніше та більш швидке засвоєння навчальних декларативних знань iз предмета «Інформаційні технології у фармації», представлених у вигляді прототипів когнітивних структур людини, про що свідчать:

1. Результати вхідного тестового контролю, оброблені за допомогою 1-тесту для незалежних вибірок, підтвердили кращу в середньому на $10 \%(\mathrm{p}<0,05)$ теоретичну підготовку студентів експериментальної групи, які в процесі підготовки до тестування працювали над вправами у форматі когнітивних структур.

2. Побудова лінії тренду успішності студентів контрольної та експериментальної груп протягом десяти занять дало змогу побачити істотну різницю між кутами нахилу цієї лінії 3 коефіцієнтами 0,067 та 0,111 у контрольній та експериментальній групах відповідно. Це може свідчити про стабільне прискорення нарощування рівня засвоєння знань студентами експериментальної групи відносно контрольної.

3. Коефіцієнт детермінації $Я^{2}$ на графіку результатів тестування експериментальної групи $(0,94)$ ближчий до одиниці ніж для контрольної $(0,7)$ групи засвідчив більш явну лінійну залежність між номером заняття та середньою оцінкою за вхідний тестовий контроль, що також можна інтерпретувати як більш послідовне, більш передбачуване (майже лінійна залежність) та стабільне нарощування знань студентів експеримен тальної групи від першого до останнього заняття.

Перспективи дослідження полягають у подальшому розвитку технології навчання через розширення спектра завдань для розкриття зв'язків між спорідненими когнітивними прототипами у рамках теми, предмета та на міжпредметному рівні з метою формування у студентів на ментальному рівні повної моделі знань у форматі когнітивних прототипів як найточніше наближеної до еталонної.

3. Микешина Л. А. Эпистемология и когнитивная наука: базовые категории и принципы взаимодействия / Л. А. Микешина // Когнитивный подход : науч. монография. - М. : Канон+, РООИ «Реабилитация», 2008. - С. 20 57.

4. Попова 3. Д. Когнитивная лингвистика / 3. Д. Попова, И. А. Стернин - М. : АСТ, Восток-Запад, 2007. - 315 с. 
5. Рыжов А. А. Алгоритмы формирования учебных элементов на основе структуры универсального класса объектов в интеллектуальных системах обучения / А. А. Рыжов, А. Н. Попов // Медична та біологічна інформатика і кібернетика: Перший Всеукраїнський з'їзд з міжнародною участю, 23-26 червня 2010 р. : збірник праць. - К. : НМАПО імені П. Л. Шупика, 2010. - С. 120.

6. Рыжов А. А. Когнитивный прототип как практический базис для структуризации и представления учебных декларативных знаний в ИСДО / А. А. Рыжов, А. Н. Попов // Клиническая информатика и Телемедицина. - 2012. - $\mathrm{N}^{\circ} 1$. - C. 133-138.

7. Рыжов А. А. Разработка и использование WYSIWYG WEB - редактора для создания эталонной модели учебного курса на основе когнитивных прототипов / А. А. Рыжов, А. Н. Попов // Тези доповідей Всеукраїнської науково-методичної відеоконференції з міжнародною участю «Актуальні питання дистанційної освіти та телемедицини 2013»Запорожье : ЗГМУ, 2013. - С. 83.

8. Рыжов А. А. Программная реализация элементов когнитивных технологий в системе дистанционного обучения / А. А. Рыжов, А. Н. Попов // Материалы науч. - прак- тич. конференции «Интеллектуальные системы принятия решений и проблемы вычислительного интеллекта (ISDMCI'2013)»- Херсон : ХНТУ 2013. - Т. 2. - С. 273-274.

9. Рижов О. А. Ефективність самостійної роботи студента над комп'ютерно-генерованими учбовими завданнями на основі когнітивних прототипів / О. А. Рижов, А.М. Попов, Н. Г. Васильчук // Медична інформатика та інженерія. 2014. - № 3. - С. 24-31.

10. Стернин И. А. Когнитивная интерпретация в лингвокогнитивных исследованиях / И. А. Стернин // Вопросы когнитивной лингвистики. - 2004. - № 1. - С. 65-69.

11. Kalyuga S. Assessment of learners' organized knowledge structures in adaptive learning environments / S. Kalyuga // Applied Cognitive Psychology. - 2006. - № 20. - P. 333-342. 12. Margolis E. Concepts: Core Readings / E. Margolis, S. Laurence. - Massachusetts: MIT Press. - 1999. - 616 p. 13. Ryzhov A. Web-oriented Educational System for Supporting Students' Learning Activity Based on Cognitive Prototypes / A. Ryzhov, A. Popov // International Journal of e-Education, e-Business, e-Management and e-Learning. 2014. - Vol. 4., No. 4. - P. 310-320. 